\title{
Electrochemical and Microstructural Analysis of FeS Films from Acidic Chemical Bath at Varying Temperatures, pH, and Immersion Time
}

\author{
Ladan Khaksar, ${ }^{1}$ Gary Whelan, ${ }^{1}$ and John Shirokoff ${ }^{2}$ \\ ${ }^{1}$ Department of Mechanical Engineering, Faculty of Engineering and Applied Science, Memorial University of Newfoundland, \\ St. John's, NL, Canada A1B 3X5 \\ ${ }^{2}$ Department of Process Engineering, Faculty of Engineering and Applied Science, Memorial University of Newfoundland, \\ St. John's, NL, Canada A1B 3X5 \\ Correspondence should be addressed to John Shirokoff; shirokof@mun.ca
}

Received 10 March 2016; Revised 30 June 2016; Accepted 21 July 2016

Academic Editor: Yu Zuo

Copyright (c) 2016 Ladan Khaksar et al. This is an open access article distributed under the Creative Commons Attribution License, which permits unrestricted use, distribution, and reproduction in any medium, provided the original work is properly cited.

\begin{abstract}
The corrosion resistance and corrosion products of 4130 alloy steel have been investigated by depositing thin films of iron sulfide synthesized from an acidic chemical bath. Tests were conducted at varying temperatures $\left(25^{\circ} \mathrm{C}-75^{\circ} \mathrm{C}\right)$, $\mathrm{pH}$ levels $(2-4)$, and immersion time (24-72 hours). The corrosion behavior was monitored by linear polarization resistance (LPR) method. X-ray Diffraction (XRD), Energy Dispersive X-ray (EDX) spectroscopy, and Scanning Electron Microscopy (SEM) have been applied to characterize the corrosion products. The results show that, along with the formation of an iron sulfide protective film on the alloy surface, increasing temperature, increasing immersion time, and decreasing $\mathrm{pH}$ all directly increase the corrosion rate of steel in the tested experimental conditions. It was also concluded that increasing temperature causes an initial increase of the corrosion rate followed by a large decrease due to transformation of the iron sulfide crystalline structure.
\end{abstract}

\section{Introduction}

The corrosion of steel in aqueous environments containing hydrogen sulfide $\left(\mathrm{H}_{2} \mathrm{~S}\right)$ is of great interest to the oil and gas industry [1-5]. Unlike carbon dioxide corrosion, $\mathrm{H}_{2} \mathrm{~S}$ corrosion always involves the formation of corrosion products that are predominantly iron sulfide (FeS) compounds with various phases. These corrosion product films should be characterized to illustrate the corrosion mechanism. It has been reported that the formation of the FeS generally controls the $\mathrm{H}_{2} \mathrm{~S}$ corrosion [6]. However, there is still debate on how the initial corrosion product layers form.

It is well known that surface scale formation is one of the most important factors that influences the corrosion rate [7]. The scale slows down the corrosion process by presenting a diffusion barrier for the species involved in the corrosion process and by covering and preventing the underlying steel from further dissolution. The scale growth depends primarily on the kinetics of scale formation [8].
$\mathrm{H}_{2} \mathrm{~S}$ corrosion on the metal surface is also strongly dependent on the type of corrosion product films formed on the surface of the metal during the corrosion process. The precipitation rate or the formation of these films depends on various environmental factors and the concentration of species. The stability, protectiveness, and adherence of these films determine the nature and the rate of corrosion $[9,10]$. It is important to note that, in contrast to one single type of iron carbonate formed in $\mathrm{CO}_{2}$ corrosion, many types of $\mathrm{FeS}$ may form during $\mathrm{H}_{2} \mathrm{~S}$ corrosion such as amorphous ferrous sulfide, mackinawite, cubic ferrous sulfide, smythite, greigite, pyrrhotite, troilite, pyrite, and marcasite [11-18].

In aqueous solutions of $\mathrm{H}_{2} \mathrm{~S}$, two mechanisms were proposed for the formation of FeS films, namely, dissolution of iron followed by precipitation of $\mathrm{FeS}$ and sulfide ion adsorption followed by direct film formation [19].

The first proposed theory is a possible mechanism for FeS formation in that the FeS layer is formed by precipitation only when its concentration reaches the solubility limit, 
analogous to how precipitation equilibrium governs the mechanism of iron carbonate formation. However, if this is to be true, the kinetics of FeS formation must be much faster than that of iron carbonate. In cases where FeS is highly undersaturated in the bulk, it can still be formed on the steel surface. This is suspected to be due to the high surface $\mathrm{pH}$ caused by consumption of hydronium ions by corrosion as well as locally high ferrous ion concentration, resulting in supersaturation of FeS on the steel surface. Therefore, FeS forms relatively fast on the steel surface, irrespective of the bulk conditions [20-22]. Another possible theory has been proposed by Shoesmith et al., which describes the idea that the first layer of mackinawite is generated by a direct, solidstate reaction between the steel surface and $\mathrm{H}_{2} \mathrm{~S}[2,19]$. Mackinawite then grows with time. The corrosion product layer growth rate depends upon the corrosion rate as well as the water chemistry with regard to $\mathrm{pH}$, temperature, and so forth. It has been found that when the thickness of FeS reaches a critical value, this corrosion product layer cracks due to the development of internal stresses [6,23]. More corrosive species such as $\mathrm{H}_{2} \mathrm{~S}$ or hydrogen ions diffuse through the now porous FeS layer and attack the steel surface. More FeS is then formed by either solid-state reaction between steel and $\mathrm{H}_{2} \mathrm{~S}$ akin to what happened initially or precipitation of FeS due to local FeS supersaturation. This direct, solid-state reaction theory is supported by other researches [24, 25].

How FeS initially forms is pertinent, because it can help to better predict the $\mathrm{H}_{2} \mathrm{~S}$ corrosion. However, until now research efforts have not achieved agreement on this subject. The situation is complicated by the variety of types of FeS that can be formed. Depending on the conditions relating to the corrosion environments, mackinawite, pyrrhotite, greigite, smythite, marcasite, and pyrite are the six naturally occurring FeS minerals $[5,19]$.

Most of the previous studies in this area are conducted at high temperatures and usually in gaseous $\mathrm{H}_{2} \mathrm{~S}$ environment. In the present study, all the experiments are performed at lower temperature in an aqueous solution because the real temperature of some oil and gas production and pipelines is below $100^{\circ} \mathrm{C}$. In this study, FeS films have been synthesized on the metal alloy surface without the presence of $\mathrm{H}_{2} \mathrm{~S}$ in the solution. Rather, FeS was formed by chemical bath deposition of iron and sulfur ions at acidic $\mathrm{pH}$ levels under varying environmental conditions.

\section{Experimental Procedure}

2.1. Material and Sample Preparation. According to NACE MR0175/ISO 15156, the most common steel alloy for tubulars and tubular components in sour service is UNS G41XX0, formerly AISI 41XX [26]. 4130 steel is among the most common alloys used in industry. This steel typically consists of $0.80-1.1 \mathrm{Cr}, 0.15-0.25 \mathrm{Mo}, 0.28-0.33 \mathrm{C}, 0.40-0.60$ $\mathrm{Mn}, 0.035 \mathrm{P}, 0.040 \mathrm{~S}, 0.15-0.35 \mathrm{Si}$, and balanced Fe. The working electrode was machined from the parent material into cylinders having dimensions of approximately $9 \mathrm{~mm}$ length and diameter. Prior to the experiments, all specimens were polished with Coated Abrasive Manufacturers Institute
(CAMI) grit designations 320, 600, and 1000 corresponding to average particle diameters $36.0,16.0$, and 10.3 microns and finally 6-micron grit silicon carbide paper and then cleansed with deionized water until a homogenous surface was observed. Following this, the specimens were quickly dried using cold air to avoid oxidation.

\subsection{Electrolyte Solution Preparation and Synthesis of FeS Films.} Due to the inherent safety concerns associated with $\mathrm{H}_{2} \mathrm{~S}$ gas, an alternative method of FeS film deposition was employed [27]. The alternative method provided an acidic electrolyte solution which has the potential to form thin FeS layer on the steel surface like what happens in the sour oil pipeline.

This acidic chemical bath contains $6.25 \mathrm{~g}$ iron (II) chloride $(0.15 \mathrm{M}), 12.60 \mathrm{~g}$ urea $(1 \mathrm{M})$, and $31.55 \mathrm{~g}$ thioacetamide $(2 \mathrm{M})$. Deionized water was used as the solvent in every experiment. Each reagent was mixed with $210 \mathrm{~mL}$ of deionized water, stirred with a magnetic stir rod for 30 minutes, and mixed together under stirring for additional two hours to achieve a clear solution.

The mechanism of FeS formation in this acidic bath is the slow release of iron and sulfur ions within solution followed by the deposition of these ions on the alloy surface. The iron and sulfur ions are provided from iron (II) chloride and thioacetamide, respectively. The formation of FeS films from this acidic bath is dependent on whether the deposition rate of the ionic product of iron and sulfur is higher than solubility of FeS. Adding urea to the solution adjusted the balance between hydrolysis and deposition. The proposed reactions for this mechanism are described as follow [27]:

$$
\begin{aligned}
\mathrm{FeCl}_{2} & \longrightarrow \mathrm{Fe}^{2+}+2 \mathrm{Cl}^{-} \\
\mathrm{CH}_{3} \mathrm{CSNH}_{2}+\mathrm{H}_{2} \mathrm{O} & \longleftrightarrow \mathrm{S}^{2-}+\mathrm{CH}_{3} \mathrm{CONH}_{2}+2 \mathrm{H}^{+} \\
\mathrm{CO}\left(\mathrm{NH}_{2}\right)_{2}+\mathrm{H}_{2} \mathrm{O} & \longleftrightarrow 2 \mathrm{NH}_{3}+\mathrm{CO}_{2} \\
\mathrm{NH}_{3}+\mathrm{H}_{2} \mathrm{O} & \longleftrightarrow \mathrm{NH}_{4}^{+}+\mathrm{OH}^{-} \\
\mathrm{Fe}^{2+}+\mathrm{S}^{2-} & \longleftrightarrow \mathrm{FeS}
\end{aligned}
$$

Finally, the overall reaction would be written as

$$
\begin{aligned}
\mathrm{Fe}^{2+} & +\mathrm{CH}_{3} \mathrm{CSNH}_{2}+\mathrm{CO}\left(\mathrm{NH}_{2}\right)_{2}+2 \mathrm{H}_{2} \mathrm{O} \\
\longrightarrow & \mathrm{FeS}+\mathrm{CH}_{3} \mathrm{CONH}_{2}+2 \mathrm{NH}_{4}{ }^{+}+\mathrm{CO}_{2}
\end{aligned}
$$

2.3. Corrosion Tests. Experiments were conducted in a multiport glass cell with a three-electrode setup at atmospheric pressure based on the ASTM G5-94 standard for potentiostatic anodic polarization measurements [28]. A graphite rod was used as the counter electrode (CE) and saturated silver/silver chloride $(\mathrm{Ag} / \mathrm{AgCl})$ was used as the reference electrode (RE). In order to investigate the electrochemical characteristic of the corrosion films formed on the steel alloy, the specimens subjected to corrosion were used as working electrodes (WE).

An Ivium Compactstat Potentiostat monitoring system was used to perform electrochemical corrosion measurements. Linear Polarization Resistance (LPR) technique was 
TABLE 1: Experimental conditions.

\begin{tabular}{lccc}
\hline $\begin{array}{l}\text { Condition } \\
\text { number }\end{array}$ & Temperature $\left({ }^{\circ} \mathrm{C}\right)$ & $\mathrm{pH}$ & Immersion time (hour) \\
\hline 1 & 50 & 4 & 24 \\
2 & 50 & 4 & 48 \\
3 & 50 & 4 & 72 \\
4 & 25 & 4 & 24 \\
5 & 50 & 4 & 24 \\
6 & 75 & 4 & 24 \\
7 & 50 & 2 & 24 \\
8 & 50 & 3 & 24 \\
9 & 50 & 4 & 24 \\
\hline
\end{tabular}

used to investigate the corrosion rate. The applied potential range for the LPR measurements was from $-0.02 \mathrm{~V}$ to $0.02 \mathrm{~V}$ with a scanning rate of $0.125 \mathrm{mV} / \mathrm{s}$. All the measurements were conducted by setting the potentiostat to take measurements at $0.5,1,2,4, \ldots$ to 24,48 , or 72 hours depending on the test. Prior to start of each test, the sample was immersed in the solution for 55 minutes in accordance with ASTM G5-82 [28]. The $\mathrm{pH}$ was adjusted by adding deoxygenated hydrochloric acid.

Table 1 describes the experimental conditions. Three series of experiments were conducted to investigate the effect of temperature, immersion time, and $\mathrm{pH}$ on the corrosion behavior of FeS films.

\subsection{Surface Morphology Observation and Corrosion Product} Analysis. Upon completion of corrosion testing, morphological characterization of the surface was conducted using FEI Quanta 400 Scanning Electronic Microscope (SEM) with Bruker Energy Dispersive X-ray (EDX) spectroscopy. The SEM was operating at $15 \mathrm{kV}$, with a working distance of $15 \mathrm{~mm}$ and beam current of $13 \mathrm{nA}$. The crystal structure and chemical composition of the corrosion products were characterized by X-ray Diffraction (XRD) using a Rigaku Ultima IV X-ray diffractometer operating at $40 \mathrm{kV}$ and $44 \mathrm{~mA}$ and SEM-EDX to confirm the chemical elements.

\section{Results and Discussion}

3.1. Effect of Immersion Time on the Corrosion Mechanism and Products. Figure 1 shows the effect of 24, 48, and 72 hours of immersion time on the corrosion rate of the specimens at $50^{\circ} \mathrm{C}$ and $\mathrm{pH}$ 4. During a corrosion process, the rate of the reaction is determined by the corrosion mechanism. Growth of a corrosion film limits the rate of further corrosion by acting as a diffusion barrier for the species involved in the process. Gradually the corrosion rate decreases and the underlying steel is protected from further dissolution [8, 19]. Figure 1 indicates that in this experiment the results of LPR measurements did not agree well with the idea of a decrement of corrosion rate by increase of exposed time to the solution. It shows that corrosion rate is increasing gradually

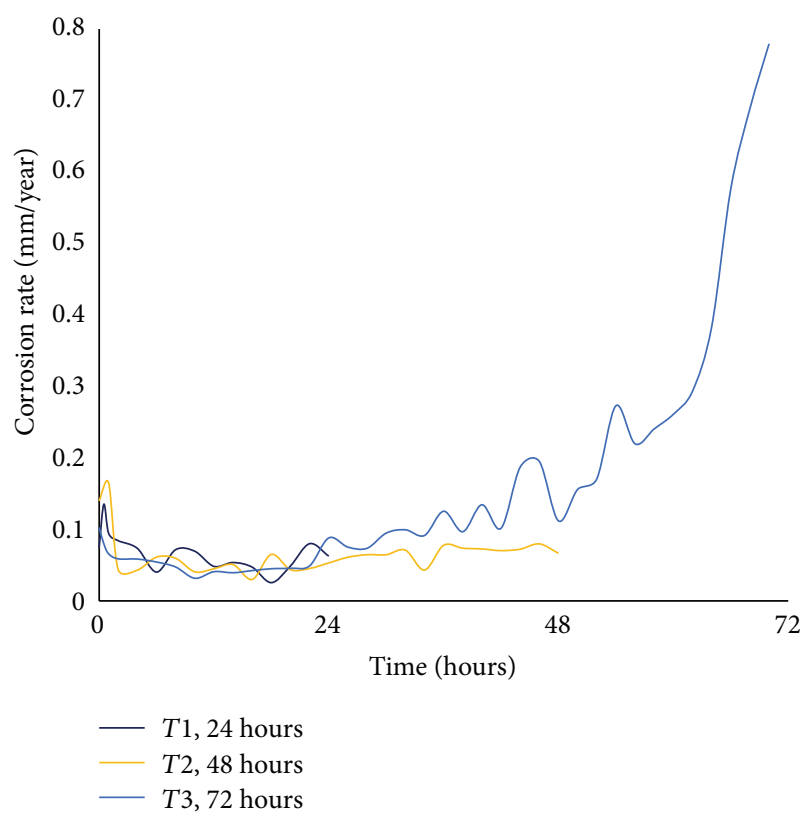

Figure 1: Corrosion rate with time at $\mathrm{pH} 4$ and $50^{\circ} \mathrm{C}$.

by increasing the immersion time which could be explained as follows:

(1) The corrosion rate is significantly greater than the rate of film formation on the surface.

(2) The corrosion product has weak adherence to the alloy surface causing it to detach and expose the unprotected alloy to the corrosive solution and increase the possibility of localize corrosion on the surface.

The diffraction spectra in Figure 2 were search-matched to the XRD computer database (i.e., contains powder diffraction files (PDF) from the joint committee on powder diffraction standards (JCPDS) and international center for diffraction data (ICDD)). Figures 2(a)-2(d) identified 006-0696 iron Fe (alpha-Fe body centered cubic (bcc) crystal type), and Figure 2(e) identified both 006-0696 iron Fe (alpha-Fe bcc) and 015-0037 mackinawite FeS (tetragonal FeS crystal type). These PDF numbers and names appear in the top right corner of each diffraction spectra and corresponding line positions are superimposed onto the spectral peaks in each figure.

Figure 2 shows the results of crystal structure characterization of the steel alloy surfaces with powder- (P-) XRD. From Figures $2(\mathrm{a})-2(\mathrm{c})$ it is apparent that $\mathrm{XRD}$ results primarily indicated elemental Fe consistent with the uncorroded sample in Figure 2(d); this is likely a result of inadequate film thickness for detection by a P-XRD spectrometer. The thin nature of the corrosion film on the surface of the steel alloy is consistent with literature discussing the deposition of FeS using the indicated chemical bath alternative to $\mathrm{H}_{2} \mathrm{~S}$ exposure [24].

As shown in Figure 2(e), there was a small amount of mackinawite detected by the P-XRD spectrometer on the surface of the sample exposed to $75^{\circ} \mathrm{C}$ for 24 hours at $4 \mathrm{pH}$. 


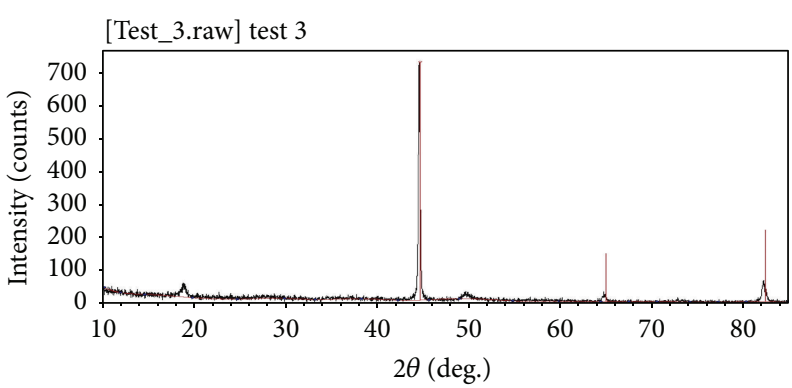

00-006-0696 > Iron, Fe

(a)

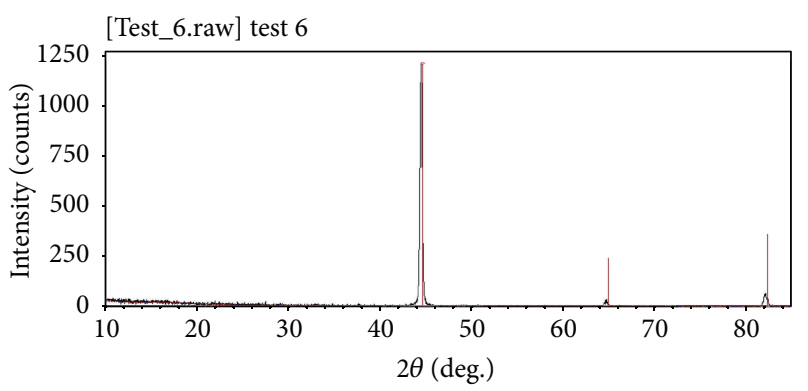

00-006-0696 > Iron, Fe

(c)

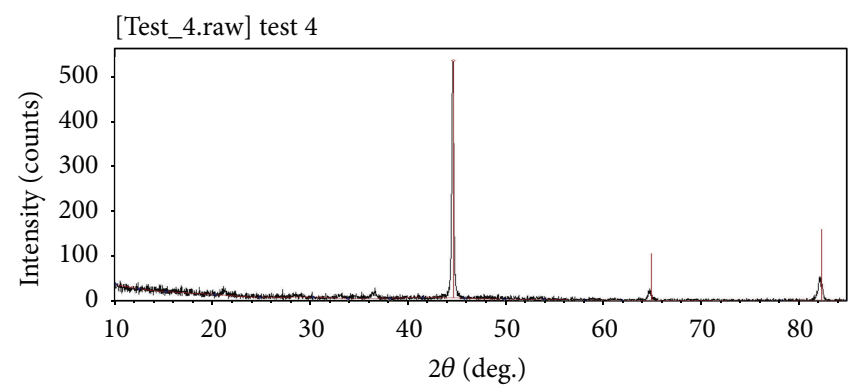

00-006-0696 > Iron, Fe

(b)

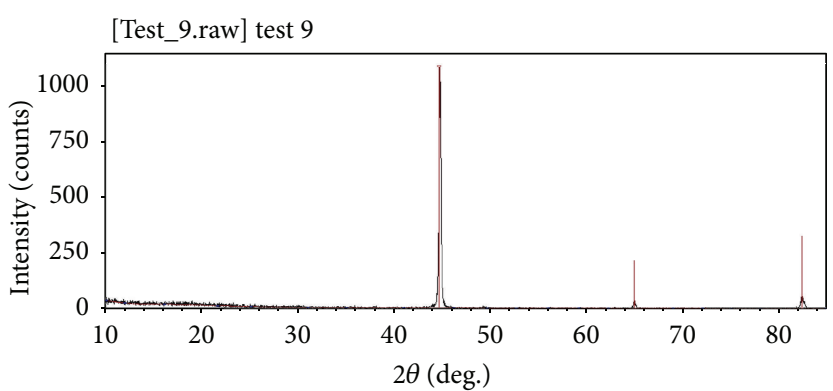

00-006-0696 > Iron, Fe

(d)

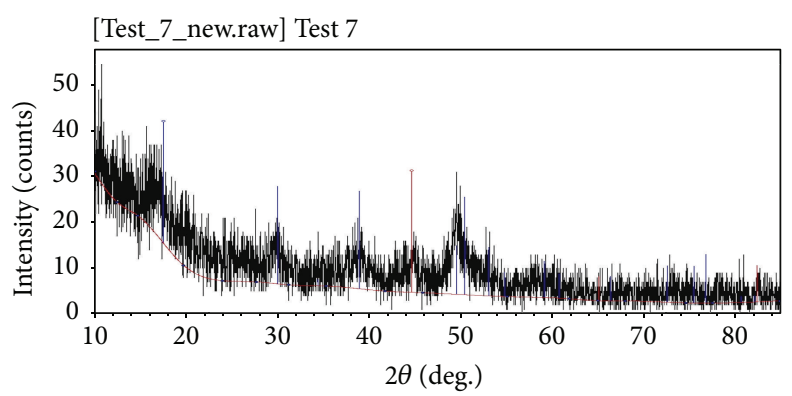

00-006-0696 > Iron, Fe

00-015-0037 > Mackinawite, FeS

(e)

Figure 2: P-XRD analysis on the 4130 alloy surface at (a) $50^{\circ} \mathrm{C}, 4 \mathrm{pH}$, and 48 hours, (b) $25^{\circ} \mathrm{C}, 4 \mathrm{pH}$, and 24 hours, (c) $50^{\circ} \mathrm{C}, 2 \mathrm{pH}$, and 24 hours, (d) initial condition (uncorroded sample), and (e) $75^{\circ} \mathrm{C}, 4 \mathrm{pH}$, and 24 hours.

This result suggests that the film thickness is increased at high temperatures. In lieu of thin film XRD analysis, P-XRD may be able to detect thicker corrosion layers formed at relatively high temperatures.

Figure 3 shows the SEM images of corrosion product films formed under varying immersion time. After 24-hour immersion time, a uniform layer of corrosion product, consisting of small tetragonal mackinawite, covered the surface [29]. As shown in Figure 3(a), this thick corrosion layer is loose and full of blister and cracks, causing the corrosion rate to accelerate by increasing the diffusion of electrochemical reaction species such as $\mathrm{Fe}^{2+}$ through the alloy surface. As has been mentioned in other researches, this initial mackinawite layer is easily cracked and peeled off due to stress as a result of the volume effect [30]. This failure of the initial corrosion layer will gradually increase the corrosion rate and expose more unprotected area to the solution.

Figure 3(b) shows the EDX analysis results of corrosion product films after 24-hour immersion. These results indicated that most of the corrosion products are iron-rich compounds such as mackinawite, which generally has lower corrosion resistance compared to sulfur-rich compounds such as troilite. The corrosion resistance of FeS follows a sequence of mackinawite $<$ troilite and $<$ pyrrhotite $<$ pyrite [24].

After 48-hour immersion, the corrosion scale cracks become more severe and hexagonal crystals form beside the cracks as shown in Figure 3(c). The EDX results of these hexagonal crystals indicate high sulfur content in their chemical composition as shown in Figure 3(d). 


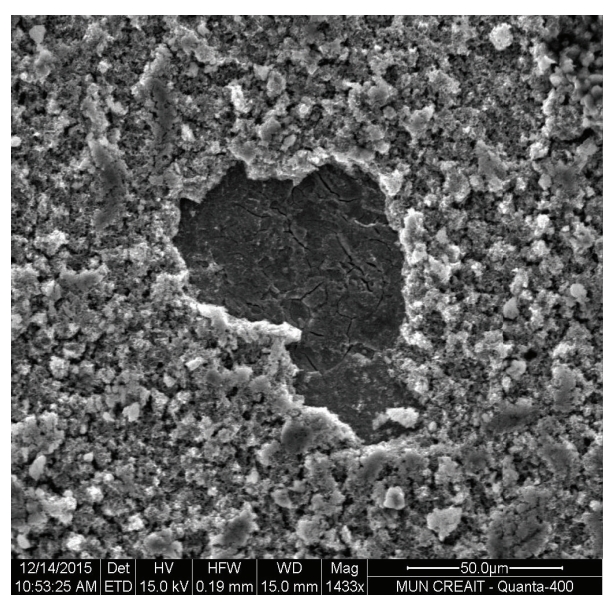

(a)

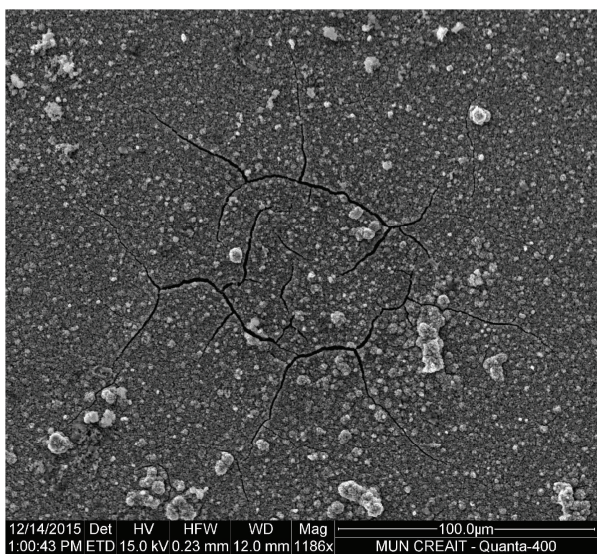

(c)

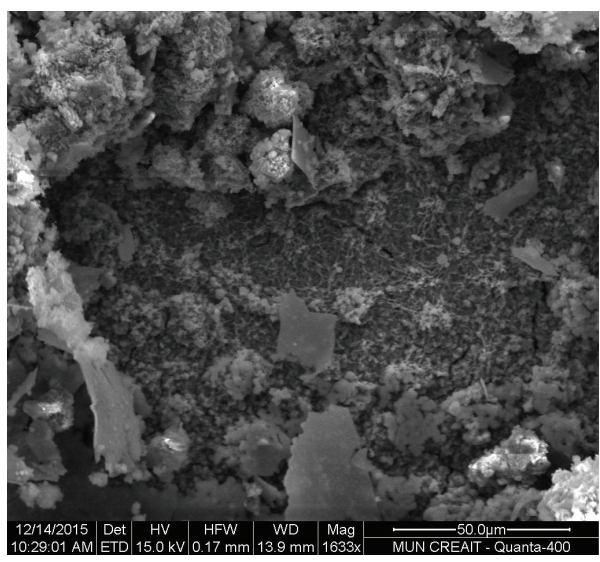

(e)

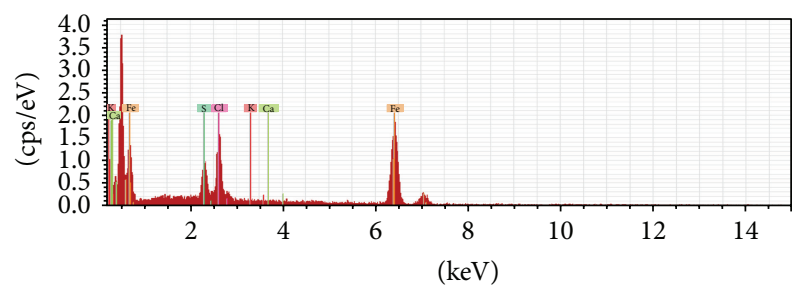

(b)

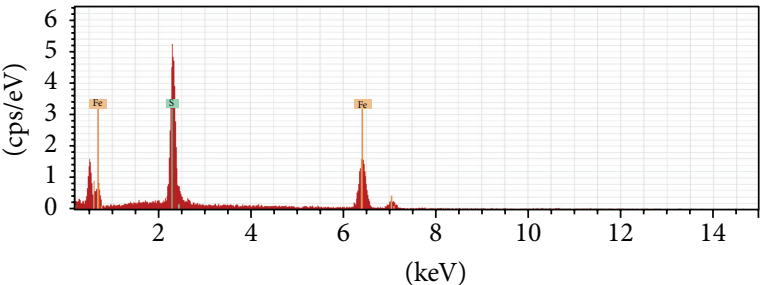

(d)

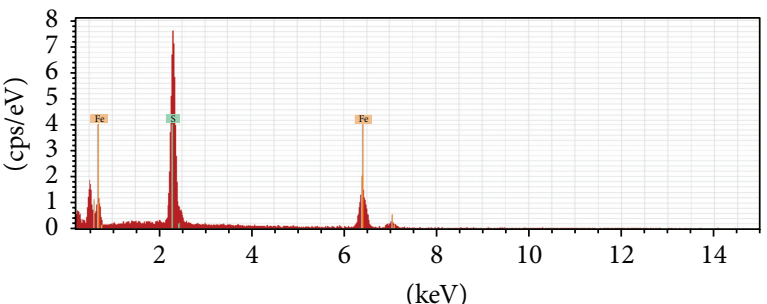

(f)

Figure 3: SEM analysis of corrosion products of 4130 alloy after (a) 24-, (c) 48-, and (e) 72-hour immersion at pH 4 and $50^{\circ} \mathrm{C}$ and $\mathrm{EDX}$ analysis of corrosion products of 4130 alloy after (b) 24-, (d) 48-, and (f) 72-hour immersion at $\mathrm{pH} 4$ and $50^{\circ} \mathrm{C}$.

Figure 3(e) shows that, after 72 hours of immersion, the initial corrosion product film has cracked and peeled off the surface of the specimen and a newly formed corrosion scale has been integrated. Larger, hexagonal shaped corrosion products formed on top of the new scale as mainly troilite crystals formed near the end of the 72 hours.
Generally, it could be said that by increase of immersion time more corrosion resistant products such as troilite replaced the initially formed mackinawite on the alloy surface. This is supported by the EDX results that indicate the major corrosion product varied from iron-rich mackinawite to sulfur-rich troilite, in Figures 3(b), 3(d), and 3(f). Despite 


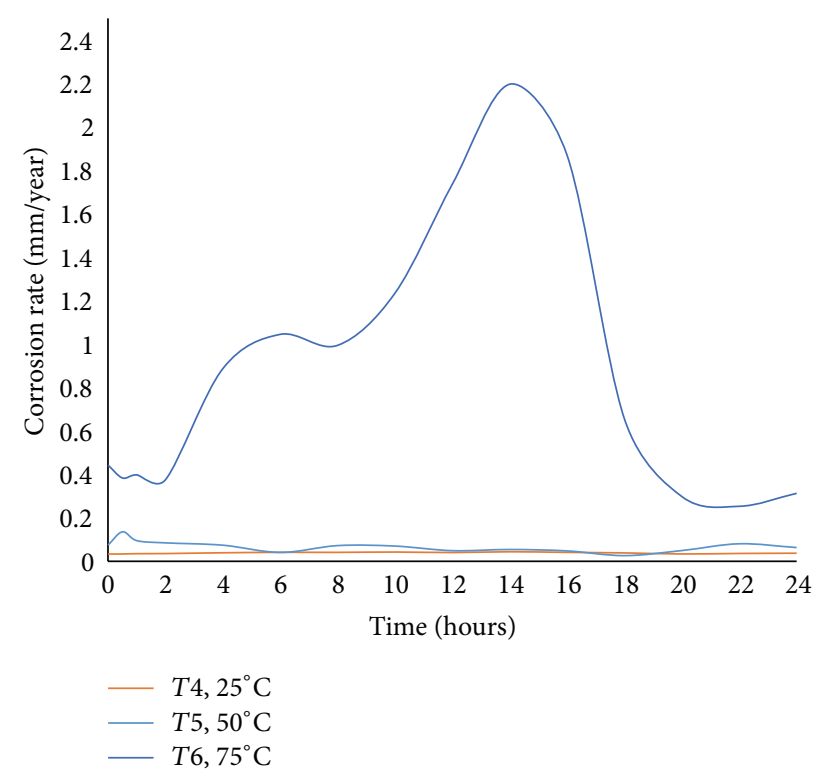

FIgURE 4: Corrosion rate with temperature at $\mathrm{pH} 4$ and 24 hours.

the nucleation of stable troilite crystals on the metal surface, the results of LPR measurements showed that between 48 and 72 hours the corrosion rate dramatically increased from 0.0662 to 0.779 . This increase could be explained by localized fracture of the corrosion film due to weak adhesion of the scale on the surface. This provides a path for sulfide to penetrate and attack the substrate of metal surface.

3.2. Effect of Temperature on the Corrosion Mechanism and Products. Figure 4 shows the effect of increasing temperature on the corrosion rate of specimens over the course of 24 hours at $\mathrm{pH} 4$.

It can be observed that, during first 12 hours of increasing temperature from $25^{\circ} \mathrm{C}$ to $75^{\circ} \mathrm{C}$, the corrosion rate dramatically increased which can be explained by the following reasons:

(1) Increasing the temperature could accelerate the diffusion of species involved in electrochemical reactions.

(2) Temperature could affect the concentration of corrosion species by preferentially evaporating one or more species out of the solution, which could affect the corrosion reaction.

It has been confirmed by previous research that temperature generally accelerates most of the chemical, electrochemical, and transporting processes occurring during the corrosion process and also both cathodic reactions and anodic currents which were measured increased with increasing temperature [31].

During the final 12 hours of testing at $75^{\circ} \mathrm{C}$, the corrosion rate significantly decreases from 2.2 to $0.25 \mathrm{~mm} /$ year, which could be related to transformation of mackinawite crystalline structure to a more resistant troilite crystalline structure. The SEM images in Figure 5 show significant fracturing of the

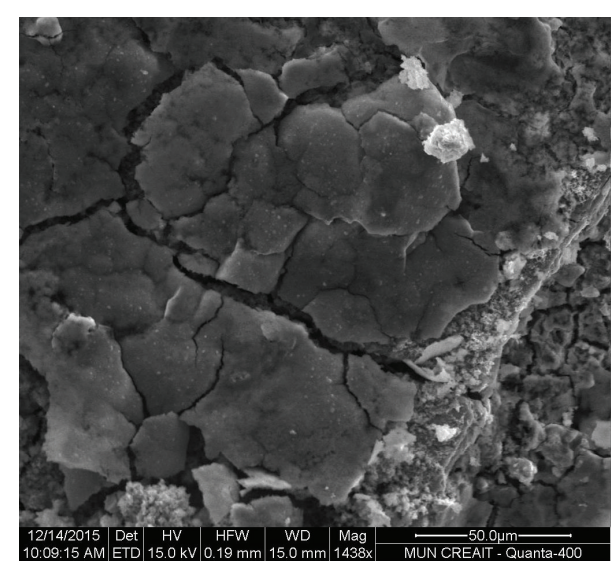

FIGURE 5: SEM image of corrosion products on surface of 4130 alloy after 24-hour immersion at $\mathrm{pH} 4$ and $75^{\circ} \mathrm{C}$.

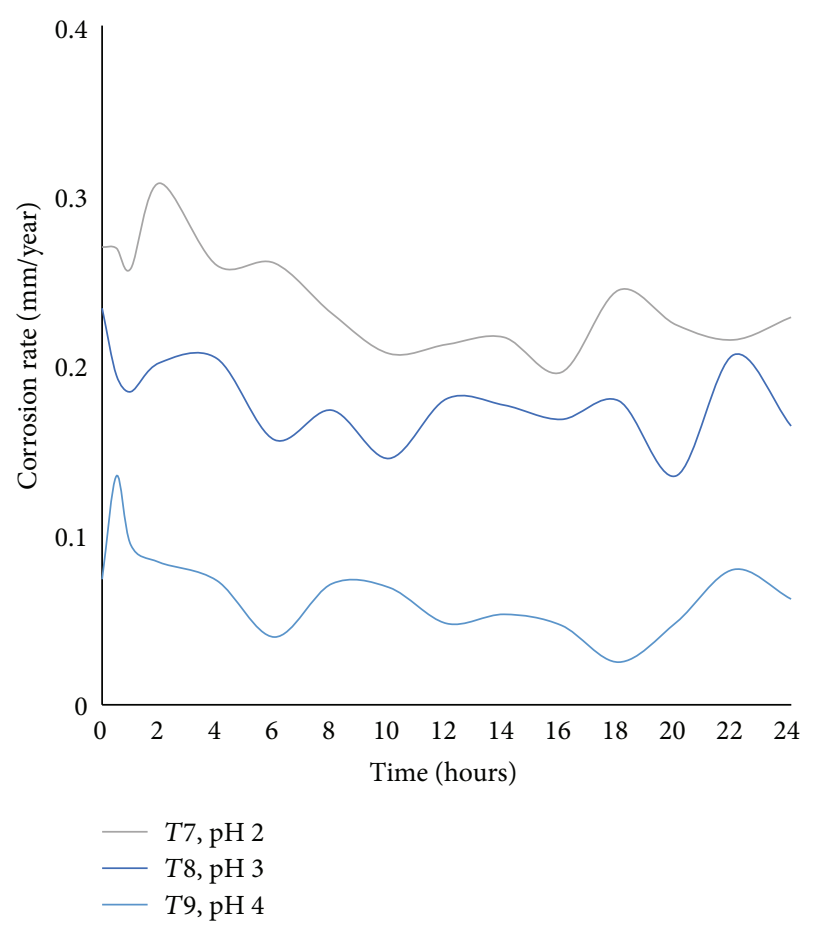

FIgURE 6: Corrosion rate with $\mathrm{pH}$ at $50^{\circ} \mathrm{C}$ and 24 hours.

surface film at $75^{\circ} \mathrm{C}$ which explains the initial higher corrosion rate due to the diffusion of species into nonprotective mackinawite followed by the decreased corrosion rate due to formation of the protective troilite crystalline structure on the alloy surface.

3.3. Effect of $p H$ on the Corrosion Mechanism and Products. Figure 6 shows the effect of $\mathrm{pH}$ on the corrosion rate of specimens immersed for 24 hours at $50^{\circ} \mathrm{C}$.

The results show that decreasing $\mathrm{pH}$ from 4 to 2 slightly increases the corrosion rate. The protective nature and composition of the corrosion product depend greatly on the $\mathrm{pH}$ of the solution. At lower values of $\mathrm{pH}(<3)$, iron is dissolved 


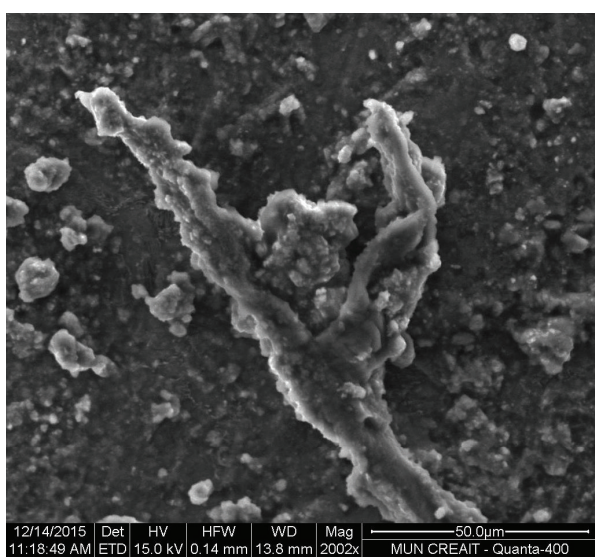

(a)

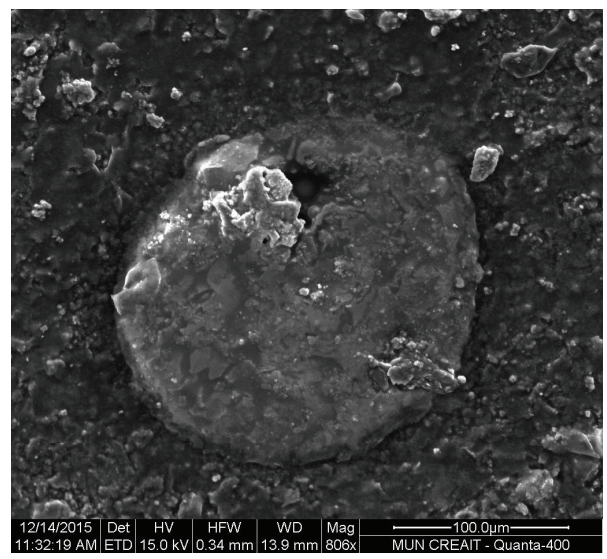

(c)

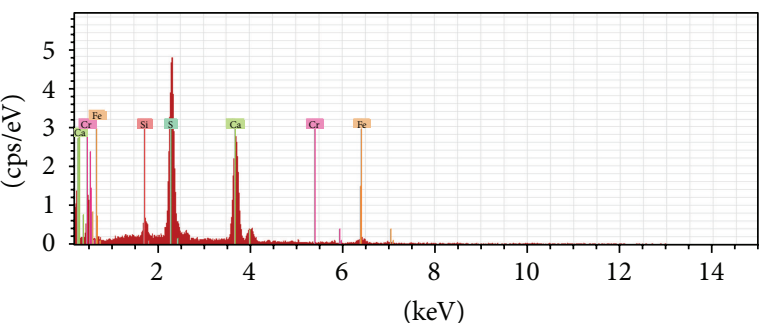

(b)

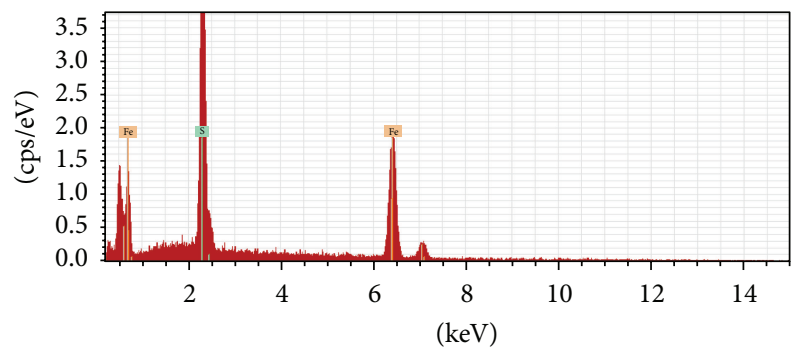

(d)

Figure 7: ((a) and (c)) SEM images of corrosion products on surface of 4130 alloy after 24-hour immersion at $50^{\circ} \mathrm{C}$ and $\mathrm{pH} 2$ and((b) and (d)) EDX analysis of corrosion products on surface of 4130 alloy after 24 -hour immersion at $50^{\circ} \mathrm{C}$ and $\mathrm{pH} 2$.

and FeS is mostly inhibited from precipitating on the metal surface due to very high solubility of FeS phases [32]. Figure 7(a) shows the SEM image of corrosion products on the surface of a specimen after 24 hours at $\mathrm{pH} 2$ and $50^{\circ} \mathrm{C}$. As can be observed, the corrosion products are loose and detached from the surface. This could result in the products being easily removed by shear stress. The EDX results as shown in Figure 7(b) indicate a high presence of sulfur compounds and a low presence of iron compounds on the surface.

The SEM results in Figure 7(c) of the specimen immersed in the solution at $\mathrm{pH} 2$ also show the presence of a pit on the surface. This is another reason for the higher corrosion rates seen at low pH. The corrosion pit shown in Figure 7(c) has a brittle cap covering the substrate. EDX analysis indicates that this cap is primarily sulfide as shown in Figure $7(\mathrm{~d})$.

At $\mathrm{pH} 3$, the top surface layer displayed a flaky structure as seen in Figure 8. Parts of the layer had spalled off and revealed the presence of much smaller crystallites under the outer layer. It is likely that this layer is the result of the immediate precipitation of $\mathrm{Fe}^{2+}$ released by corrosion [32]. At $\mathrm{pH}$ values from 3 to 4 , an inhibitive effect of the corrosion mechanism is seen due to the formation of a marcasite FeS protective

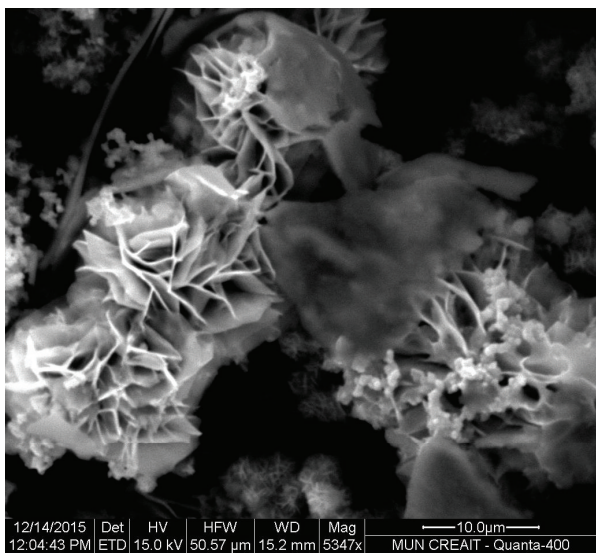

FIGURE 8: SEM image of corrosion products on surface of 4130 alloy after 24-hour immersion at $\mathrm{pH} 3$ and $50^{\circ} \mathrm{C}$.

film on the electrode surface. At $\mathrm{pH} 3$, small crystals were observed on areas where the outer layer had spalled off as shown in Figure 8. At pH 4, the surface was mostly covered with a much denser layer as shown in Figure 9. 


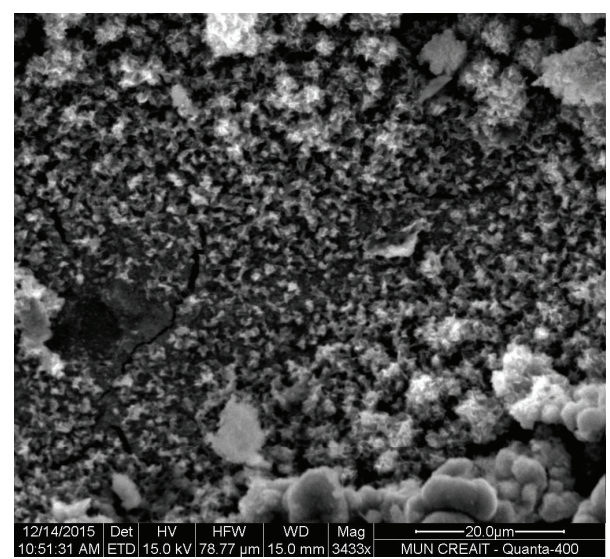

FIGURE 9: SEM image of corrosion products on surface of 4130 alloy after 24-hour immersion at $\mathrm{pH} 4$ and $50^{\circ} \mathrm{C}$.

\section{Conclusions}

The results of this research indicated that acidic chemical bath deposition could be successfully applied to investigate the formation and growth of FeS thin films under varying experimental conditions. Due to the inherent safety concerns associated with sour corrosion experiments in laboratories, this acidic chemical bath deposition method could be applied as a substitute for $\mathrm{H}_{2} \mathrm{~S}$ in certain experiments to characterize formation and transformation of FeS corrosion products.

Other primary findings of this research are as follows:

(i) Increase of immersion time gradually increases the corrosion rate of 4130 chromium alloy steel in this experiment, resulting from localize fracture of corrosion layer despite transformation of FeS crystalline structures from iron-rich mackinawite to sulfur-rich troilite compounds during the corrosion process.

(ii) Increase of $\mathrm{pH}$ directly decreases the corrosion rate of 4130 alloy steel in this experiment resulting from the formation of a more resistant FeS film at higher values of $\mathrm{pH}$.

(iii) Increase of temperature from $25^{\circ} \mathrm{C}$ to $75^{\circ} \mathrm{C}$ causes an increase in the corrosion rate of 4130 alloy steel, likewise resulting from the transformation of FeS crystalline structure during the corrosion process.

\section{Competing Interests}

The authors declare that they have no competing interests.

\section{Acknowledgments}

The research in this paper is supported by the Suncor Reservoir Souring Initiative at Memorial University of Newfoundland.

\section{References}

[1] D. W. Shoesmith, P. Taylor, M. G. Bailey, and D. G. Owen, "The formation of ferrous monosulfide polymorphs during the corrosion of iron by aqueous hydrogen sulfide at $21^{\circ} \mathrm{C}$," Journal of the Electrochemical Society, vol. 127, no. 5, pp. 1007-1015, 1980.

[2] D. W. Shoesmith, "Formation, transformation and dissolution of phases formed on surfaces," in Proceedings of the Electrochemical Society Meeting, Ottawa, Canada, November 1981.

[3] S. N. Smith and E. J. Wright, "Prediction of minimum $\mathrm{H}_{2} \mathrm{~S}$ levels required for slightly sour corrosion," in Proceedings of the Conference on Corrosion, Paper No. 11, NACE International, 1994.

[4] S. N. Smith and E. J. Wright, "Prediction of corrosion in slightly sour environments," in Proceedings of the Conference on Corrosion, Paper no. 02241, NACE International, 2002.

[5] J. S. Smith and J. D. A. Miller, "Nature of sulphides and their corrosive effect on ferrous metals: a review," British Corrosion Journal, vol. 10, no. 3, pp. 136-143, 1975.

[6] H. Fang, Investigation of localized corrosion of carbon steel in $\mathrm{H}_{2}$ S environments [Ph.D. thesis], Ohio University, Athens, Ohio, USA, 2012.

[7] W. Sun and S. Nesic, "A mechanistic model of $\mathrm{H}_{2} \mathrm{~S}$ corrosion of mild steel," Paper 07655, NACE International, CORROSION/2007, St. Pete Beach, Fla, USA, 2007.

[8] W. Sun, S. Nesic, and S. Papavinasan, "Kinetics of iron sulfide and mixed iron sulfide/carbonate scale precipitation in $\mathrm{CO}_{2} / \mathrm{H}_{2} \mathrm{~S}$ Corrosion," CORROSION/2007, NACE International, paper no. 06644, 2007.

[9] M. Koteeswaran, $\mathrm{CO}_{2}$ and $\mathrm{H}_{2} \mathrm{~S}$ corrosion in oil pipelines [M.S. thesis], University of Stavanger, Stavanger, Norway, June 2010.

[10] W. Sun, Kinetics of iron carbonate and iron sulfide scale formation in $\mathrm{CO}_{2} / \mathrm{H}_{2} \mathrm{~S}$ corrosion [Ph.D. thesis], Ohio University, Athens, Ohio, USA, 2006.

[11] P. Taylor, "The stereochemistry of iron sulfides-a structural rationale for the crystallization of some metastable phases from aqueous solution," American Mineralogist, vol. 65, pp. 1026$1030,1980$.

[12] M. Bonis, M. Girgis, K. Goerz, and R. MacDonald, "Weight loss corrosion with $\mathrm{H}_{2} \mathrm{~S}$ : using past operations for designing future facilities," CORROSION/2006, NACE International, paper no. 06122, 2006.

[13] D. Rickard and G. W. Luther, "Chemistry of iron sulfides," Chemical Reviews, vol. 107, no. 2, pp. 514-562, 2007.

[14] A. R. Lennie and D. J. Vaughan, "Spectroscopic studies of iron sulfide formation and phase relations at low temperatures," Mineral Spectroscopy, vol. 5, pp. 117-131, 1996.

[15] L. Smith and B. Craig, "Practical corrosion control measures for elemental sulfur," in Proceedings of the Conference on Corrosion, Paper No. 05646, pp. 1-20, NACE International, 2005.

[16] B. N. Brown, The influence of sulfides on localized corrosion of mild steel [Ph.D. thesis], Ohio University, 2013.

[17] T. Laitinen, "Localized corrosion of stainless steel in chloride, sulfate and thiosulfate containing environments," Corrosion Science, vol. 42, no. 3, pp. 421-441, 2000.

[18] J. Kvarekval, "Morphology of localised corrosion attacks in sour environments," CORROSION/2007, NACE International, paper no. $07659,2007$.

[19] K. J. Lee, A mechanistic modeling of $\mathrm{CO}_{2}$ corrosion of mild steel in the presence of $\mathrm{H}_{2} S$ [Ph.D. thesis], Ohio University, 2004.

[20] N. G. Harmandas and P. G. Koutsoukos, "The formation of iron(II) sulfides in aqueous solutions," Journal of Crystal Growth, vol. 167, no. 3-4, pp. 719-724, 1996. 
[21] J. Amri and J. Kvarekvål, "Simultation of solid state growth of iron sulfide in sour corrosion conditions," Paper 11076, NACE International, CORROSION/2011, St. Pete Beach, Fla, USA, 2011.

[22] N. S. P. Obuka, O. N. Celestine, G. R. O. Ikwu, Chukwumuanya, and E. Okechukwu, "Review of corrosion kinetics and thermodynamics of $\mathrm{CO}_{2}$ and $\mathrm{H}_{2} \mathrm{~S}$ corrosion effects and associated prediction/evaluation on oil and gas pipeline system," International Journal of Scientific \& Technology Research, vol. 1, no. 4, pp. 156$162,2012$.

[23] A. G. Wikjord, T. E. Rummery, F. E. Doern, and D. G. Owen, "Corrosion and deposition during the exposure of carbon steel to hydrogen sulphide-water solutions," Corrosion Science, vol. 20, no. 5, pp. 651-671, 1980.

[24] S. N. Smith, "A proposed mechanism for corrosion in slightly sour oil and gas production," in Proceedings of the 12th International Corrosion Congress, vol. 4, pp. 2695-2706, NACE International, Houston, Tex, USA, September 1993.

[25] D. Rickard, "Kinetics of FeS precipitation: part 1. Competing reaction mechanisms," Geochimica et Cosmochimica Acta, vol. 59, no. 21, pp. 4367-4379, 1995.

[26] Petroleum and Natural Gas Industries, "Materials for use in $\mathrm{H}_{2} \mathrm{~S}$ containing environments in oil and gas production," Tech. Rep. NACE MR0175/ISO 15156-1, 2001.

[27] M. Saeed Akhtar, A. Alenad, and M. Azad Malik, "Synthesis of mackinawite FeS thin films from acidic chemical baths," Materials Science in Semiconductor Processing, vol. 32, pp. 1-5, 2015.

[28] ASTM-G5-82, "Standard reference method for making potentiostatic and potentiodynamic anodic polarisation measurements," Annul B. ASTM Standards vol. 03.02, 1982, Reapproved as ASTM-65-87 and as ASTM-65-94, pp. 511-521, 1982.

[29] P. Bai, S. Zheng, H. Zhao, Y. Ding, J. Wu, and C. Chen, "Investigations of the diverse corrosion products on steel in a hydrogen sulfide environment," Corrosion Science, vol. 87, pp. 397-406, 2014.

[30] M. Liu, J. Wang, W. Ke, and E.-H. Han, "Corrosion behavior of X52 anti- $\mathrm{H}_{2} \mathrm{~S}$ pipeline steel exposed to high $\mathrm{H}_{2} \mathrm{~S}$ concentration solutions at 90॰C," Journal of Materials Science and Technology, vol. 30, no. 5, pp. 504-510, 2014.

[31] Y. Zheng, B. Brown, and S. Nesic, "Electrochemical study and modeling of $\mathrm{H}_{2} \mathrm{~S}$ corrosion of mild steel," in Proceedings of the Corrosion, Paper no. 2406, pp. 1-22, NACE International, 2013.

[32] B. Valery, Effect of pre-exposure of sulfur and iron sulfide on $\mathrm{H}_{2} \mathrm{~S}$ Corrosion at different temperatures [M.S. thesis], University of Stavanger, 2011. 

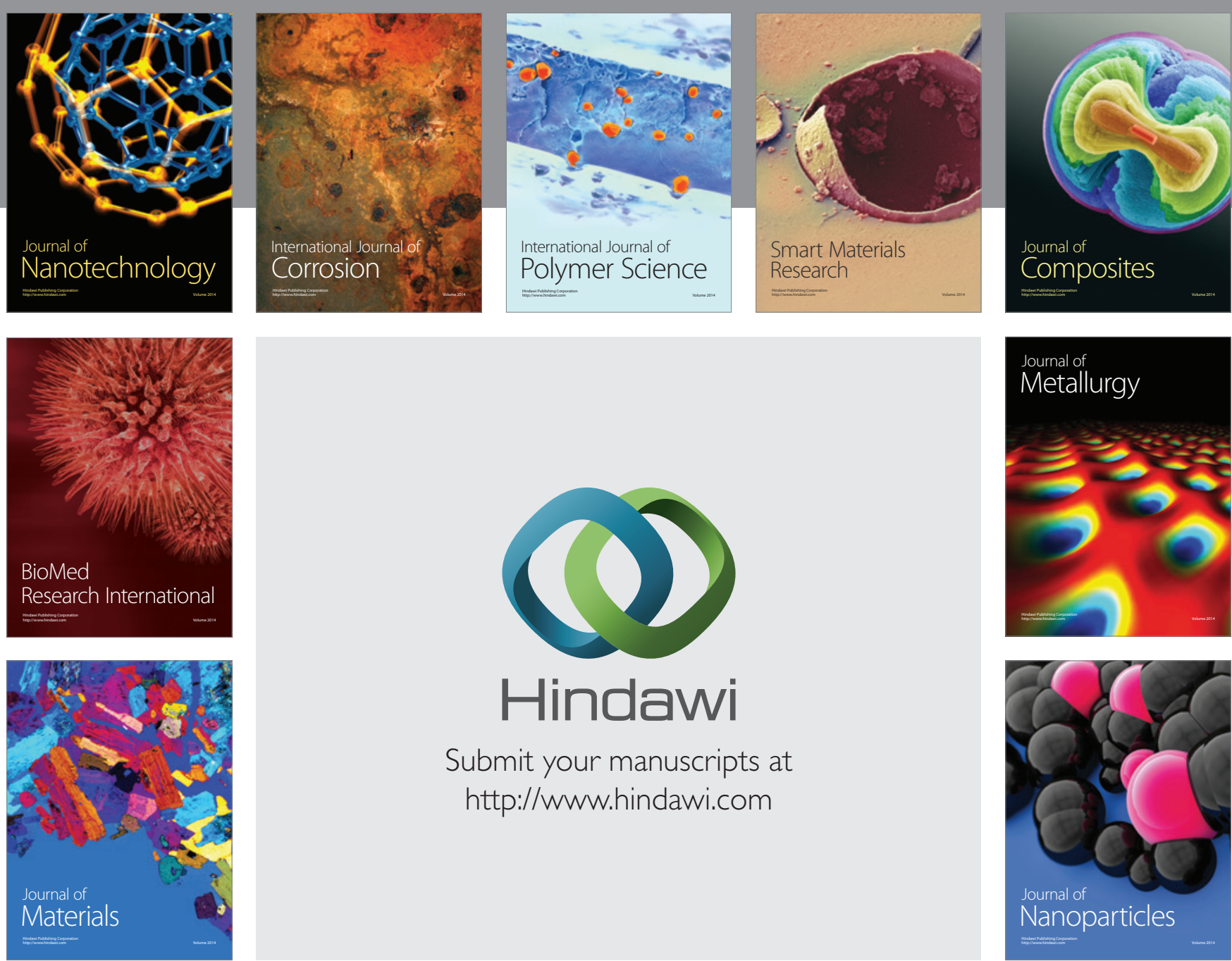

\section{Hindawi}

Submit your manuscripts at

http://www.hindawi.com

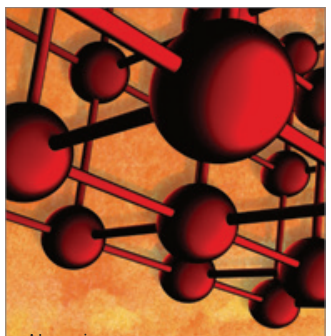

Materials Science and Engineering
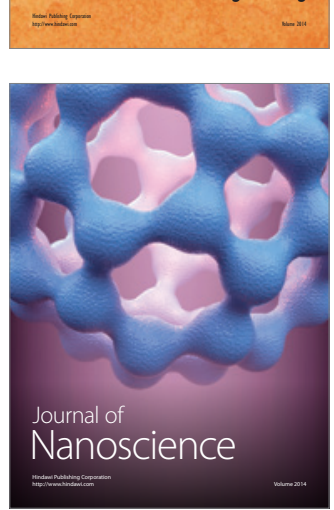
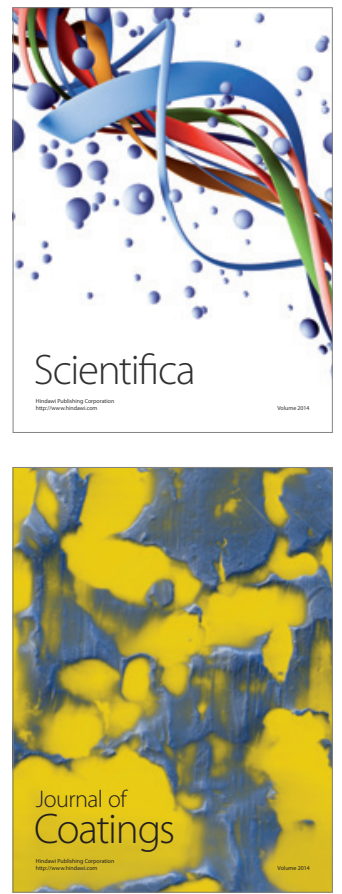
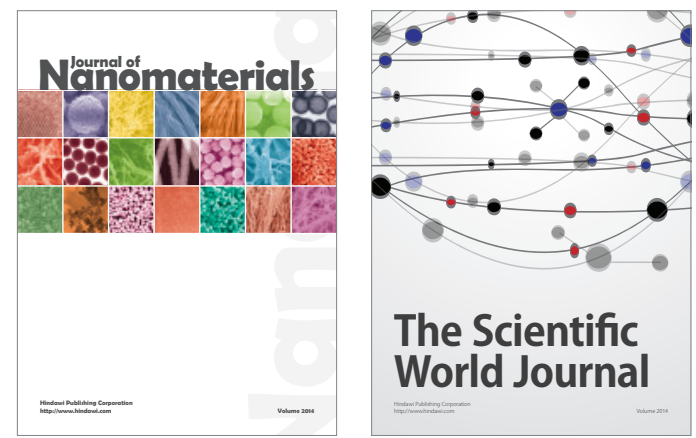

The Scientific World Journal
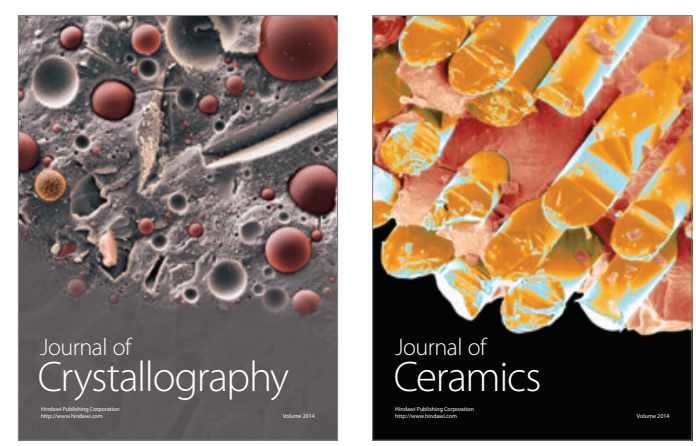
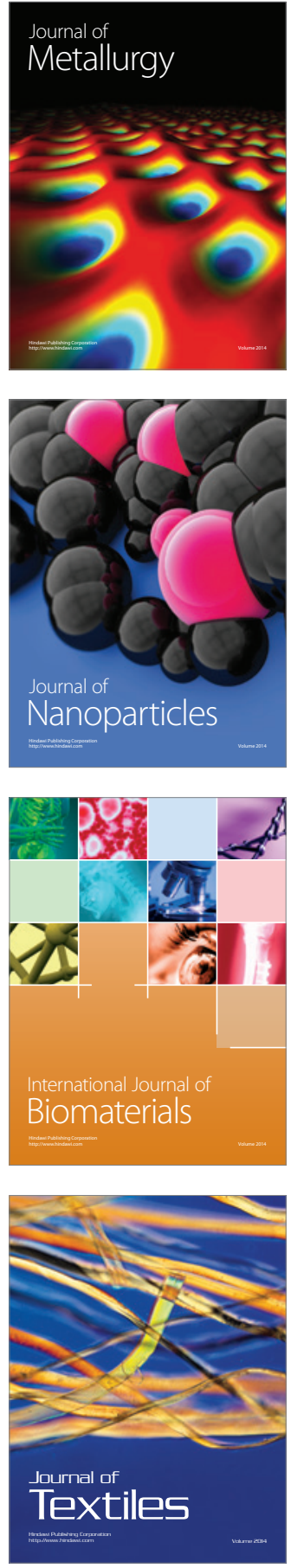